\title{
IMPACT OF REMITTANCES ON EXPORT PERFORMANCE : TIME SERIES EVIDENCE FROM PAKISTAN
}

\author{
Muhammad Asif Shamim1 \\ Assistant Professor, Bahria University Karachi, \\ Dr.Iqbal Ahmed Panhwar 2 \\ Professor,Bahria University Karachi \\ Syed Muhammad Ahsan Rizvi3 \\ Associate Professor \\ Bahria University Karachi \\ Ehsan Ahmed Shaikh 4 \\ Assistant Professor \\ Govt. Degree Boys College, 5L, North Karachi, Karachi
}

\begin{abstract}
Purpose:This study analyzes the relationship between Remittance and Exports by using 32 years timeseries data from the period 1981 to 2012.

Methodology:This study includes Regression analysis OLS, Granger causality test, , Eigenvalue test, stability analysis ,Augmented DickyFuller tests ,Error correction model, cointegaration and sensitivity analysis.

Finding:The results show the negative effect of remittance on exports in the long run in Pakistan which is completely against previous studies to date.

Implications:The Government of Pakistan should lower the barriers to remittance flows and reduce the transaction cost for migrants who send money home and make export market more competitive to have significant positive impact of remittances on export.
\end{abstract}

Keywords : Export, Remittances, Real Gross Domestic Product

Jel Classification: F1, F24, E160, C23

\footnotetext{
* The material presented by the author does not necessarily portray the viewpoint of the editors and the management of the Institute of Business \& Technology (IBT)

1 Muhammad Asif Shamim

2 Dr.Iqbal Ahmed Panhwar

3 Syed Muhammad Ahsan Rizvi

4 Ehsan Ahmed Shaikh

: asifshamim@bimcs.edu.pk

: iqbal.panhwar@bimcs.edu.pk

: ahsanrizvi@bimcs.edu.pk

(C) IBTJBS is published by the Institute of Business and Technology (IBT).

Main Ibrahim Hydri Road, Korangi Creek, Karachi-75190, Pakistan.
} 


\section{INTRODUCTION}

Pakistan Remittances Initiative was introduced by State Bank of Pakistan, Ministry of Finance and Ministry of Overseas Pakistanies, in 2009 with the view to overcome persistent current account deficit because remittances are considered to be the most important for foreign exchange inflows in developing countries like Pakistan. This is because foreign remittances are far greater than the official development assistance and foreign private capital. This makes developing countries less dependent on other sort of inflows for meeting their foreign exchange requirements. However, remittances can lead to the overshooting of a country's exchange rate, a phenomenaknown as the Dutch disease.

In this connection Bourdet and Falck (2006) found a negative effect of foreign remittance and foreign aid on the country's external competitiveness for Cape Verdean economy. As remittances are financial inflows, they may be associated with monetary aggregates of an economy. Likewise, they may influenced by monetary policy of the country. That is why models used for studying the effect of remittances on economic performance of any developing country may experience uncertainty because of the role of central bank.

An empirical study by Hyder and Mahboob (2006) found that one percentage point of GDP increase results in appreciating Pakistan's real exchange rate by 0.16 percent. This study aims at investigating relationship between exports performance and remittance for the economy of Pakistan using the data ranging from 1981 to 2012. Though, there is a theoretical justification of the relationship between remittances and exports performance, empirical study is the dire need of the economy of Pakistan.

\section{LITERATURE REVIEW}

\subsection{Theoretical Framework}

It is often argued that a migrant's remittances are the biggest external source of financial aid coming into developing countries compared to FDI and foreign aid. However, the question that still remains unanswered is that if such private flows promote economic growth? Those who are against the argument criticize that remittances do not contribute to growth rather they become part of conspicuous consumption and that any savings from them are being spent on consumption rather than for additions to productive capacity and this leads to low marginal propensity to consume out of transitory income. Those in favor of the argument criticize that the role of multiplier effect of consumption, role of financial institutions, the use of remittances in form of foreign exchange and an debt solution helps ease anindividual's credit worthiness within a country. These arguments are divided into two approaches for economists; top-down approach where the main focus is on the development of institutions therefore alleviating poverty and the bottom-up approach where main focus is to remove the individuals from the poverty trap.

There is a possibility of exchange rate overshooting, a phenomenon which is termed 
as dutch disease. This results in making a country's exports relatively expencive and its imports relatively cheaper, thereby putting pressure on its trade account. Remmited money gives rise to additional demand thereby increasing prices in non-tradable, which in turn increases prices in tradable sector. This situation results in reallocating resources from tradable sectors i.e industry and agriculture to non-tradable sector i.e services. This reallocation of resources makes a small economy's tradable sector less competetive. Overseas Pakistanis' remittances merged from one to ten percent of GDP. This is favourably compares with other sort of foreign capital inflows. This situation is comparable with other developing countries. It is also said that the source of economic growth in developing or recipient countries is through 'export led growth' which is channeled through remittances. Yet again a question arises if these overseas remittances affect the competitiveness of the 'export sector' in the recipient countries? The four channels can affect the competitiveness of the respective sector. First, the recipient country is supposed to promote the growth of non-tradable sector compared to the tradable, hence affecting competitiveness through Dutch disease effect. Second, since exporting labor is cheaper as compared to exporting commodities (as it requires efforts to produce) the international migration and export sector are afraid to compete on the tradable products. One positive aspect of this is that it establishes strong links between home and host countries since international migration to host countries brings information in form of language, skills, knowledge, preference etc. Finally, the fourth channel is in form of direct capital investment. Direct capital investment enhances the growth of export sector and also improves the credit worthiness and overall economic stability of the recipient country.

\subsection{Empirical Framework}

A lot of research has been conducted in order to studied the relationship between FDI and remittances. These researches concluded varied results regarding the relationship between both the variables as discussed below:

Marwan et al (2013) examined the role of export, aid and remittance inflows in relation to economic growth in Sudan by using time series data from year 1977 to 2010. Export is used as dependent variable and remittance as independent variable using the Johansen Co-integration technique within the augmented Solow-model approach. Result indicates long-run positive relationship between the variables. It is suggested that contemporary capital such as remittances is required along with greater trade liberalization. Khathlan (2012) found the relationship between remittances and economic growth. This study employed data ranging from 1976 to 2010. In this study real GDP was used as dependent variable whereas remittances and inflation were used as independent variables. The study employed ARDL approach and error correction model. Results found a positive relation between remittances and economic growth. Similarly, he found a positive and significant impact of FDI on economic growth both in short and long run. Outcomes of the study suggested that Pakistan can increase economic stability by raising economic activity on the external front.

Kumar (2011) explore how Remittances, Exports and Financial Development effects Economic Growth of Pakistan by using time series data from 1980 to 2009 by using real GDP as dependent variable and worker income as independent variable. Bound tests technique is applied; results indicate that exports are significant both in the short 
run and long run but the remittances having significant positive impact on economic growth in the long run, while financial development having significant effect in the long run. It is suggested that government should developed exports and remittances market for the economic growth and economic sustainability.

Kumar (2011) additionallydiscovered the role of financial services, information and communications technology, remittance inflows and export liberalization in Nepal over the periods 1975-2010. By using income level as dependent variable and financial development, telecommunications, remittance inflows and export as independent variables. ARDL Bounds approach has been applied. Results indicate positive relationship between the variables both, in the short run and long run. It is recommended that Nepal's government should provide labour mobility schemes and promote export to establish Nepal.

Kock and Sun (2011) investigated the forces that have driven remittance flows to Pakistan in recent years. 12 years data has been used from 1997-2008 i.e. time series data by using key aspects of traditional studies of drivers of remittances. No. of variables have been used such as migration, worker's skills, economic conditions in the host country, making use of OLS approach and Bayesian model. Results show that increases in remittances are because of increase in labor migration and the economic boon in the GCC countries. It is suggested that In the long run remittances will depend on rise in labor migration.

Makhlouf and Mughal (2011) inspected the effects of Remittances on Dutch Disease in Pakistan, by using Time Series Data from 1999 to 2011. The Remittances were taken as dependent variable, while GDP and Economic Growth were used as independent variable. Probabilistic Bayesian paradigm technique was applied. This study finds that aggregate level of remittances from Europe and Gulf cause Dutch disease but those USA do not. It is suggested that the the impact of rimittances on external competitiveness may be overcome using fiscal policy judiciously, by enhancing productivity of labour and by introducing a progressive taxation system.

Kumar and Ronald (2011) observed the Impact of Information and communications technology, financial development, trade openness, remittances on Nepal Economy by using Time series data from 1975-2010. By using Labor output as dependent variable and Remittances as Independent variables. Autoregressive Distributed Lag (ARDL) model was applied. The result indicates there is a negative relation in Long run while positive relation in short runs. It is suggested that Government should promote incentivizing foreign direct investment and boosting manufacturing sector operations and the need for good governance practices in public service operations. Fayad (2011) in Remittances: Dutch disease or export-led growth used time series data from 1980 to 1990 taking export-led growth as an dependent variable and remittances as an independent variable by using OLS, 2SLS techniques and Hansen test, results indicate positive relationship between the variables. He suggested that in order to increase exports, government should promote policies that help to increase flow of remittances in a country. 
Siddique et al (2010) examine the relationship between Remittances and economic growth in Bangladesh India and sri-lanka, by using time series data from 1976 to 2006 by using real GDP as dependent variable and remittance as an independent variable. In this study unit root test, co-integration and causality is applied, the results indicate that there is no effects of growth on remittances in economic growth both in India and Bangladesh while in Sri-lanka bi-directional causal relation between the variables is found. The outcome of the study suggested that several important areas need to be improved remittances in order to enhance economic growth such as Transmission mechanisms and channelizing the remittances, Gender Issues, Regulation and Enforcement, Investment and Savings Schemes and Promotion and Education. Semyenov and Gorodzeisky(2008) observedLabor Migration, Remittances and Economic Well-being of Households in the Philippines, using time series data from 1999-2000 by using labor migration and remittances as independent variables and well-being of households as dependent variables. The findings are that due to remittances the income of households with overseas labor migrants is considerably higher than income of households without overseas labor.

Pant (2008) examined Mobilizing Remittances for Productive Use: A Policy-oriented Approach by using time series data from 2003-2008 by using remittances as independent variable and economic growth as dependent variable. Analytical approach technique was put into effect and results indicate there is positive relation between the variables in short and long run. It is suggested that government should Bring recipient households into the formal financial sector, as it is only the first step in using remittances more effectively.

Fayissa et al (2008) looked at the Impact of Remittances on Economic Growth and Development in Africa by using time series data from 1980 to 2004 for 37 African countries by using remittances as independent variable and economic growth as dependent variable. The simple fixed-effects and random-effects model technique is used, results indicates that there is positive relation between the variables in short as well as in the long run of the African countries. It is suggested that government should promote the simple fixed-effects and random-effects model in the country to promote Economic Growth and Development.

Rao et al (2007) delved into development performance of Pasific Islands in which time series data from 1975-2003 has been used. FDI, foreign aid, remittances, migration were used in this study. Results shows no impact of FDI on growth, on the other hand migration is due to political problems and better living. Foreign debt and growth have negative relationship.

Rao and Takirua (2006) analysed the impact of aid, remittances and exports on productivity. The rate of growth of output was employed as dependent variable, and GDP and the export ratio as independent variable. The GETS and JMLVECM technique was used and results indicate that technical progress, remittances and aid impacts negatively while exports positively.

Iqbal and Sattar(2005) examine the workers' remittances contribution in Pakistan's 
growth for the period 1972 to 2003. They used growth as dependent variable and remittances as independent variable using the multiple regression framework . Results indicate positive relation between the variables and authors recommend that government should formulate more wise policies, provide attractive investment opportunities and explore new markets for manpower exports.

El-Sakka(2004) reviewed the how macroeconomic policies affect emigrant remittances in Jorden by using time series data from 1970-2002. By using remittances as independent variable and level of income at home as a dependent variable. The model used was a macro model to estimate the total inflow of remittances. The study finds a positive relationship between level of income in domestic economy and remittances inflows. As Jordon's income increases inflow of remittances rise and vice versa. Buch et al (2002) analysed the analysis of Worker Remittances and their relationship with other capital flows. By using Time Series Data from 1970 to 1999 By using Capital flows as an dependent variable while Remittances as an independent variable He used Correlation Analyses technique. Results indicates that the economic analysis of workers' remittances has been in the debate of globalization in general, particularly in international finance. Remittances were typically considered significant for some smaller economies. In these economies remittances are used for consumption purpose and have limited impact on investment and growth

Puri and Ritzema (1999) weighed the effect of remittances on economies labour exporting countries. These countries focused exclucivily on officially recorded inflows ang their effects on formal sector of the economy. By using time series data from the years 1983-1999 and by taking remittances as independent variable and domestic economies as dependent variables. This study finds remittances likeages are a reflection of policy regime of labour exporting countries. Hence their development significance can be increased by introducing policy reformce so that macroeconomic fundamentals may be put in order at house. Secondly, remittances inflows through official channels ought to be encouraged through the use of micro finace instruments and by reforming the existing banking system so that informal market arrangements may be curbed. Nishat and Bilgrami (1991) reviewed the Impact of rimittances on Pakistan's growth employing data from 1960 to 1988, using remittances as independent variables and GNP, consumption, investment and imports as dependent variables , and applying standard Keynesian Macro-economic model. The results suggest that among the other dependent variables, remittances show the largest impact on consumption and the smallest impact on private investments. It is suggested that government should aim at efficient channeling of remittances into productive investment and sustain the inflow of remittances exploring new markets of manpower.

Stahl and Habib (1989) inspected the relation between remittances and outflow/output using time series data from 1976-1987 ,by taking remittances as independent variable and outflow/output as dependent variable, in a price endogenous computable general equilibrium model (CGE). Results indicate that 13\% of expenditures out of remittances are directed toward imported goods. It is suggested that the government should encourage a greater proportion of financial savings out of remittance income. 


\section{Modeling Framework}

The model to estimate the effect of remittances on the exports of Pakistan is defined below:

$$
\begin{gathered}
\text { EXP }=\mathbf{f}(\text { RGDP,RP,REM }) \\
\text { EXP }=\beta_{0}+\beta_{1} L(R G D P)+\beta_{2} L(R P)+\beta_{3} L(R E M)+C i
\end{gathered}
$$

Where;EXP is exported,RP is relative price, RGDP is of Real GDP at constant price Rs 7477.63 billion. In this model, $\beta_{1}$ and $\beta_{2}$ are expect to be greater than zero, however, sign of $\beta_{3}$ is to empirically determined. Yearly data ranging from 1981 to 2012 is employed to investigate the impact of remittances on exports growth. The data is compiled by various issues of economic survey of Pakistan. Both dependent and independent variables are in $\log$ form.

In order to test for the time series properties of data, we employ Augmented Dicky Fuller test. Our study also used Engle Granger (1987) cointegration test. However, we also employed Johasan cointegration test in orger to find long run relationship among variables. Causality Analysis, sensitivity analysis test, toda and yamamoto test are also used.

\section{ESTIMATION AND RESULTS}

Note: the critical values for ADF test with constant (C) and with constant and

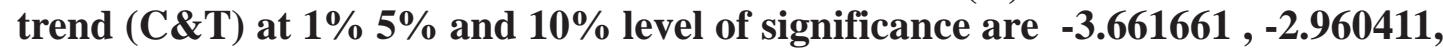
-2.619160 and $-4.284580,-3.562882,-3.215267$ respectively.

Source :Author's estimation.

The results in the Table- $4.1 \mathrm{a}$ and $4.1 \mathrm{~b}$ confirm that all variables are non-stationary at levels with both the models i.e. with constant (C) term only and with constant term (C) and linear trend $(\mathrm{T})$ and all variables are stationary at first difference in both models. The results indicate the presence log run relation, a test for cointegration is conducted. Residual based test suggested by Engle and Granger (1987) is utilized here. Variables are I(1), so Engle-Grange test is conducted Table 4.2 shows the results. The results presented in the Table 4.2 indicates that we have consistent estimates that would converge to their true values if OLS is applied to I(1).The coefficients of real GDP and RP have sign as we hypothesized and are significant. Coefficient of REM is negative and significant. These will be the valid long-run relationship, if and only if there is a conintegration. Durbin Watson (CRDW) statistics, is 1.075256 in our case.The critical value for CRDW test at 1\% level of significance is 0.511 (computed by Sargan and Bhargwa). Since the computed CRDW statistics is greater than the critical CRDW, we accept the alternative hypothsis of cointegration at the 1 percent level. We also utilise the ADF as it is recommended by Engle and Granger.

The results of stationary test using Augmented Dickey Fuller (ADF) and PhillipsPerron(PP) tests are reported in the table 4.3. The ADF and PP tests show that without linear trend the residuals are stationary at levels at 5\% level of significance and with 

linear trend the residuals are stationary at levels at $10 \%$ in case of ADF test and at 5\% in case of PP test. In short, the variables are found I(1) and the residuals are I(0), therefore we can conclude that there is a strong long run relationship between exports, RGDP, RP and REM in Pakistan.

The Engle-Granger single equation based cointegratin test has been used intensively in the literature, it does have some drawbacks. There could be more than one cointegraring vector when there more than two variables present in the model. Johansen $(1988,1991)$ developed is method and further extended by Johansed and Juselius (1990) which is normally considered superior to the Engle-Granger method. The estimated Trace and Maximum Eigen value test statistics vis-à-vis their corresponding critical values are given in Table 4.4 .

Starting with the null hypothesis of no cointegration among the variables, Trace statistics is above $5 \%$ critical value. Hence it rejects the null hypothesis of no co integration, in favor of general alternatives one cointeregating vector. Turning to the Maximum Eigen value test, the null hypothesis of no cointegration is rejected at $5 \%$ level of significance in favor of specific alternatives, that there is one cointegration vector. Thus, the results from both of two tests suggest that there exist a stable long run equilibrium relationship of real aggregate import demand with its major determinants such as RGDP, RP amd REM.

Hendry's (1980) approach is used to test for short run relation. Results are given in Table 4.5 .

We may observe from the results above that the coefficient of LREM is highly insignificant. This confirms that REM has no immediate impact on aggregate exports in the short run. The error term has negative value of coefficient as expected and is statistically significant. The low value of the coefficient of error term indicated that the model converges steadily to the equlilibrium value.

\subsection{Causality Analysis}

The direction of causality between remmitances and aggregate exports is analyzed by using Granger (1969) causality test. Table 5.1 indicates that LRGDP causes LEXP but LEXP has no impact on LRGDP therefore unidirectional relationship exist between LGDP and LEXP.Similarly, LREM cause LGDP but LGDP has no impact on LREM, therefore unidirectional relatiosip exist between these two variables. No causal relationshipsare found betweenLRP and LEXP, LREM and LEXP, and LREM and LRP.

\subsection{Sensitivity Analysis}

In this section a sensitivity analysis has been performed to test the robustness of the results. The degree of confidence among the relation between the regressand and the regressors has been established by Levine and Renelt (1992). After incorporating additional varibales in the model if coefficient of regressor remain significant and of the same sign then they refer to the result as robust. If the coefficient does not reain significant or it the coefficient changes its sign, then the assurance in the relationship between variables in less and they refer to the result as flimsy. 
In the main model log of relative price (LRP), log of income (LRGDP) and log of remittances (LREM) are chief determinants of export performance. Table 6.1 indicates the results of sensitivity analysis where we have presented the impact of remittances variable on export with the addition of different relevant variables, the coefficient of the focus variable (LREM) remains negative and statistically significant, no matter what combination of additional variables are used in the basic model. Thus, our result supports robust negative relationship between remittances and aggregate export in Pakistan.

\section{CONCLUSION AND POLICY IMPLICATIONS}

The impact of remittance on export performance in case of Pakistan has been unspecified and unexplained for a long period of time. Theoretical literature and past empirical studies suggests the positive long-run relationship between Export and Remittances. This study tries to contribute to the existing literature using time series data of Islamic Republic of Pakistan and paying due attention ot the standard econometric techniques. Our findings contradicts with the existing literature and empirial studies with the fact that there exists a negative long-run relationship between export and remittances. The error correction model results indicate that there exist no short-run relationship between Export and Remittances in Pakistan. Further more Toda and Yamamoto causality test indicates no casual relationships between Export and Remittances in Pakistan. The sensitivity analysis confirms that the results are robust. The policy implication of this study is that there is a need to establish exports and remittance markets for long-term sustainability of the country and to find ground-breaking methods to make financial sector more integrated to economic activities. There is a need to find reasons for negative relationship between export and remittances in Pakistan.

\section{ACKNOWLEDGEMENT}

First of all with a profound gratitude, we are thankful to Almighty Allah forgiving us success, knowledge and understanding without which we would not been capable of completing this research paper.

We are also profoundly grateful to all our family members whose endurance and understanding have played a significant role in our success by sacrificing the important family time and supporting us all over the research work.

We are finally thankful to the editor, reviewers and IBT specially who provided us with the opportunity to publish our research paper in this esteemed journal.

\section{REFERENCES}

Abu Siddique, E A Selvanathan and SarojaSelvanathan (2010), Remittances and Economic Growth: Empirical Evidence from Bangladesh, India and Sri Lanka, Discussion Paper 10.27, pp 1-24 BhaskaraRao, KanhaiyaLal Sharma, Rup Singh and NaliniLata (2007), A Survey of 
Muhammad Asif Shamim, Dr.Iqbal Ahmed Panhwar, Syed Muhammad Ahsan Rizvi, Ehsan Ahmed Shaikh

Buch, Claudia M.; Kuckulenz, Anja; Le Manchec, Marie-Helene (2002), Worker Remittances and Capital Flows, Kiel Institute for World Economics (IfW) DuesternbrookerWeg 120, 24105 Kiel (Germany), Kiel Working, pp 1-41

El-Sakka, M.I.T (2004) Migrant workers' remittances and macroeconomic policy in Jordan, Department of Economics: Kuwait University, pp1-22 FaridMakhlouf and Mazhar Mughal (2011), Remittances and Dutch Disease in Pakistan - a Bayesian analysis, JEL Classification: F40, F41,pp 1-36

GhadaFayad (2011), Remittances: Dutch disease or export-led growth?, Department of Economics OxCarre ResearchPaper 57, 1-30 kumar (2011) Do Remittances, Exports and Financial Development Matter for Economic Growth? A Case Study of Pakistan using Bounds Approach. Journal of International Academic Research.11(1)pp 18-26.

Khalid Al Khathlan (2012), The Link between Remittances and Economic Growth in Pakistan : A boon to Economic Satbility . British Journal of Economics, Management \& Trade 2(3) pp 167-185.

Moshe Semyenov and Anastasia Gorodzeisky (2008), Labor Migration, Remittances and Economic Well-being of Households in the Philippines, Population Research and policy review,27(5), pp 619-637

Mohammad Nishat and NighatBilgrami (1991), The Impact of Migrant Worker's Remittances on Pakistan Economy, Pakistan Economic and Social Review: Volume XXIX, No.1,pp 21-41

NurFakhzanMarwana, Nor AziahAbd.Kadirb, AdibahHussinb, Azniza Ahmad Zainib, MohdElfeeAb.Rashidb, ZulkifliAbd. GhaniHelmic (2013). The role of export, overseas development aid (ODA) and remittance inflows in relation to economic growth in Sudan, Procedia Economics and Finance, 2013,volume 7, 3-10.

Ronald R. Kumar (2011) Role of financial and Technology inclusion, remittances and exports vis-_a-vis growth: A study of , Munich Personal RePEc Archive, MPRA Paper No. 38850,pp 1-25

ShivaniPuri, TinekeRitzema(1999). Migrant Worker Remittances Micro-finance and the Informal Economy: Prospects and Issues,enterprise and cooperative Development department- social finance unit,Working Paper21,pp 1-36 UdoKockand Yan Sun (2011), Remittances in Pakistan: Why have they grown up any why aren't they coming down, IMF working paper, 11/200, pp1-26 ZafarIqbal\& Abdul Sattar (2005), Contribution of Workers' Remittances to Economic Growth in Pakistan, Pakistan Institute of Development Economics, report no. 187, pp 1-25. 


\section{APPENDIX-I}

Table 4.1a Stationary Test Results

\begin{tabular}{|l|l|l|l|l|}
\hline Variables & \multicolumn{4}{|c|}{ ADF test statistics } \\
\hline & $\mathrm{I}(0)$ & & $\mathrm{I}(1)$ & \\
\hline & $\mathrm{C}$ & $\mathrm{C} \& \mathrm{~T}$ & $\mathrm{C}$ & $\mathrm{C} \& \mathrm{~T}$ \\
\hline EXP & -1.181291 & -1.447059 & -7.048915 & -7.775602 \\
\hline RGDP & -2.452078 & -2.195386 & -3.822821 & -4.082268 \\
\hline REM & 1.189766 & -0.688372 & -4.192084 & -4.805251 \\
\hline RP & & & & \\
\hline
\end{tabular}

Table 4.1b Stationary Test Results

\begin{tabular}{|l|l|l|l|l|}
\hline Variables & \multicolumn{4}{|c|}{ PP test statistics } \\
\hline & $\mathrm{I}(0)$ & & $\mathrm{I}(1)$ & \\
\hline & $\mathrm{C}$ & $\mathrm{C} \& \mathrm{~T}$ & $\mathrm{C}$ & $\mathrm{C} \& \mathrm{~T}$ \\
\hline EXP & -1.264061 & -1.411108 & -6.932908 & -9.721838 \\
\hline RGDP & -2.223693 & -2.079867 & -3.800243 & -4.081129 \\
\hline REM & 1.698669 & -0.431208 & -4.110237 & -4.559350 \\
\hline
\end{tabular}

Table 4.2

\begin{tabular}{|l|l|l|l|}
\hline Variables & Coefficient & T-stattistics & Prob value \\
\hline C & \multicolumn{1}{|l|}{-9.260124} & -19.66009 & 0.0000 \\
\hline RGDP & 1.541597 & 32.79712 & 0.0000 \\
\hline REM & -0.081288 & -3.728355 & 0.0009 \\
\hline RP & 0.389110 & 2.195762 & 0.0366 \\
\hline $\mathbf{R}^{2}$ & 0.977391 & \\
\hline Adj. $\mathbf{R}^{\mathbf{2}}$ & 0.974968 & \\
\hline F-statistic & 403.4791 Prob(F-statistic) 0.000000 & \\
\hline D-W statistic & 1.075256 & \\
\hline
\end{tabular}


Table 4.3 ADF test for Stationary of Residual

\begin{tabular}{|l|c|c|}
\hline & Without Trend & With Trend \\
\hline ADF Test & $\mathbf{- 3 . 4 2 4}$ & $\mathbf{- 3 . 3 8 0}$ \\
\hline PP Test & $-\mathbf{3 . 6 4 8}$ & $\mathbf{- 3 . 6 1 4}$ \\
\hline $1 \%$ Critical Value & $-\mathbf{3 . 6 6 1}$ & $-\mathbf{4 . 2 8 4}$ \\
\hline $5 \%$ Crirtical Value & $-\mathbf{2 . 9 6 0}$ & $\mathbf{- 3 . 5 6 2}$ \\
\hline $10 \%$ Critical Value & $-\mathbf{2 . 6 1 9}$ & $\mathbf{- 3 . 2 1 5}$ \\
\hline
\end{tabular}

Source: Author's estimations.

Table 4.4 Cointegration Test Results

\begin{tabular}{lllll}
\hline $\begin{array}{l}\text { Null Hypothesis } \\
\text { No. of CE(s) }\end{array}$ & Trace & $\mathbf{5 \%}$ critical & Max. Eigen & $\mathbf{5 \%}$ critical \\
& Statistics & Values & Value statistics & Values \\
\hline None & 44.87447 & 40.17493 & 28.95530 & 24.15921 \\
At Most 1 & 15.91917 & 24.27596 & 10.09797 & 17.79730 \\
At Most 2 & 5.821202 & 12.32090 & 5.784783 & 11.22480 \\
At Most 3 & 0.036418 & 4.129906 & 0.036418 & 4.129906 \\
\hline
\end{tabular}

Table: 4.5 Results of Error Correction Model

\begin{tabular}{lcrr}
\hline Variable & Coefficient & \multicolumn{1}{l}{ t-Statistic } & \multicolumn{1}{l}{ Prob. } \\
\hline C & -0.055211 & -1.040609 & 0.3084 \\
D(LEXP(-1)) & 0.073846 & 0.389139 & 0.7006 \\
D(LGDP) & 2.259527 & 2.631185 & 0.0146 \\
D(LRP) & 0.230631 & 1.047048 & 0.3055 \\
D(LREM) & 0.054326 & 0.740791 & 0.4660 \\
ER(-1) & -0.476168 & -2.501769 & 0.0196 \\
Adj. $\mathbf{R}^{2}$ & 0.195511 & F- & \\
& & Statistics2.40954 \\
D.W & \multicolumn{3}{c}{ 6 } \\
\hline
\end{tabular}


Table 5.1 Causality Test Results

\begin{tabular}{lcc}
\hline \multicolumn{1}{c}{ Variables } & F-statistics & Prob. \\
\hline LRGDP does not Granger Cause LEXP & 3.48288 & 0.0725 \\
LEXP does not Granger Cause LRGDP & 0.43496 & 0.5150 \\
LRP does not Granger Cause LEXP & 0.57531 & 0.4545 \\
LEXP does not Granger Cause LRP & 0.97717 & 0.3314 \\
LREM does not Granger Cause LEXP & 0.00981 & 0.9218 \\
LEXP does not Granger Cause LREM & 0.32765 & 0.5716 \\
LRP does not Granger Cause LRGDP & 1.06511 & 0.3109 \\
LRGDP does not Granger Cause LRP & 0.80649 & 0.3768 \\
LREM does not Granger Cause LRGDP & 4.46967 & 0.0435 \\
LGDP does not Granger Cause LREM & 0.88959 & 0.3537 \\
LREM does not Granger Cause LRP & 0.03851 & 0.8458 \\
LRP does not Granger Cause LREM & 0.06341 & 0.8030 \\
\hline
\end{tabular}

Table 6.1 Results of Sensitivity Analysis

\begin{tabular}{|l|l|l|l|l|c|}
\hline Variables & Coeffi of REM & t-stat (prob.) & Adjusted R & \multicolumn{1}{|c|}{ DW stat. } & F-stat. \\
\hline Basic model & -0.081288 & $-1.796113^{*}$ & 0.974969 & 1.075255 & 403.4811 \\
\hline $\begin{array}{l}\text { Model 2 } \\
\text { LNS }\end{array}$ & -0.137954 & -2.110694 & 0.975342 & 1.175720 & 307.5544 \\
\hline $\begin{array}{l}\text { Model 3 } \\
\text { LER }\end{array}$ & -0.078690 & -5.567284 & 0.998587 & 2.609304 & 3004.120 \\
\hline $\begin{array}{l}\text { Model } 4 \\
\text { LLF } \\
\text { LER }\end{array}$ & -0.069799 & -4.475325 & 0.998643 & 3.371881 & 2503.027 \\
\hline $\begin{array}{l}\text { Model 5 } \\
\text { LER } \\
\text { LFDI }\end{array}$ & -0.082467 & -4.756860 & 0.998490 & 2.646292 & 2248.761 \\
\hline
\end{tabular}

*= significant at 10 percent level of significance.

L stands for Common Logarithm. NS= National Savings, ER= Exchange Rate, $\mathrm{LF}=$ Total Labor-Force and FDI= Foreign Direct Investment. 